\title{
Diffuse pulmonary haemorrhage accompanied by haemothorax as a rare presentation of primary lung angiosarcoma
}

\author{
Katarzyna Modrzewska ${ }^{1}$, Elżbieta Radzikowska ${ }^{1}$, Małgorzata Szołkowska ${ }^{2}$, Karina Oniszh $^{3}$, \\ Magdalena Szczęsna ${ }^{4}$, Kazimierz Roszkowski-Śliż ${ }^{1}$
}

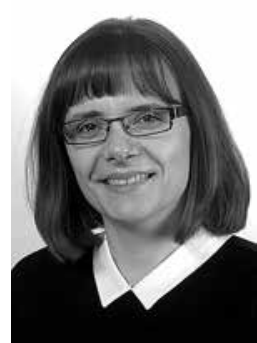

\author{
${ }^{1}$ III Department of Lung Diseases, Institute of Tuberculosis and Lung Diseases in Warsaw, Poland \\ ${ }^{2}$ Department of Pathology, Institute of Tuberculosis and Lung Diseases in Warsaw, Poland \\ ${ }^{3}$ Department of Radiology, Institute of Tuberculosis and Lung Diseases in Warsaw, Poland \\ ${ }^{4}$ Department Thoracic Surgery, Institute of Tuberculosis and Lung Diseases in Warsaw, Poland
}

Kardiochirurgia i Torakochirurgia Polska 2015; 12 (4): 367-371

\begin{abstract}
Primary pulmonary angiosarcoma is an extremely rare disease. Chest computed tomography demonstrates solitary or multifocal lesions, sometimes associated with ground-glass opacities or pleural effusion. Diagnosis is based on histological examination that reveals spindle-shaped epithelioid cells with positive staining for endothelial markers (factor VIII, CD 31, CD34, Fli-1, Ulex europaeus agglutinin 1, vimentin). The prognosis is poor and effective treatment is still being researched. This is a report of a 65-year-old patient with a four-month history of haemoptysis, cough, and dyspnoea. The primary radiological findings suggested interstitial lung disease. After one month the clinical presentation evolved into diffuse pulmonary haemorrhage with concomitant haemothorax. The diagnosis of primary lung angiosarcoma was based on histological and immunohistochemical examination of the lung and pleural biopsy obtained by videothoracoscopy.

Key words: angiosarcoma, diffuse pulmonary haemorrhage,
\end{abstract} haemothorax.

\section{Introduction}

Primary pulmonary angiosarcoma (PPA) is a rare neoplasm originating from endothelial cells of small vessels of the lung [1]. The highest incidence of the disease occurs in the fifth and sixth decade of life. Chest computed tomography (CT) demonstrates solitary or multifocal lesions occasionally accompanied by ground-glass opacities or pleural effusion [2-4]. Diffuse alveolar haemorrhage with concomitant haemothorax is an extremely rare manifestation of

\section{Streszczenie}

Pierwotny płucny naczyniakomięsak (angiosarcoma) jest niezwykle rzadką chorobą. Badanie tomografii komputerowej płuc demonstruje najczęściej pojedyncze guzy lub mnogie guzki, czasami z towarzyszącymi zmianami o typie matowej szyby lub płynu opłucnowego. Rozpoznanie ustala się na podstawie oceny histologicznej, która uwidacznia wrzecionowate komórki epitelioidalne wybarwiające się w kierunku markerów śródbłonkowych (czynnik VIII, CD 31, CD34, Fli-1, Ulex europaeus agglutinin 1, vimentina). Rokowanie jest bardzo złe, nadal poszukiwane są skuteczne metody leczenia. W pracy zaprezentowano przypadek 65-letniej pacjentki z 4-miesięcznym wywiadem krwioplucia, kaszlu i duszności. Początkowe badania radiologiczne sugerowały śródmiąższową chorobę płuc. Po miesiącu obraz kliniczny ewoluował w kierunku rozsianego krwawienia płucnego z towarzyszącym krwiakiem opłucnej. Rozpoznanie pierwotnej płucnej angiosarcomy zostało ustalone na podstawie oceny histologicznej i immunohistochemicznej bioptatów płuc i opłucnej pobranych drogą wideotorakoskopii.

Słowa kluczowe: naczyniakomięsak, rozlany krwotok płucny, krwiak opłucnej.

primary angiosarcoma of the lung. There has been only one other report published with a similar presentation [5]. The diagnosis is based on histological findings complemented by immunohistochemical stainings typical for endothelial markers. Due to high malignancy, patients with angiosarcoma have a low rate of survival. An effective therapeutic regimen is still being researched. We present a case of rapid progression of PPA manifested as bilateral pulmonary opacities and haemothorax. 


\section{Case report}

A 65-year-old smoking woman presented a four-month history of haemoptysis, cough, and dyspnoea. The patient's medical history was significant for chronic obstructive pulmonary disease (COPD), permanent atrial fibrillation (AF) under continuous anticoagulation treatment, hypertension, and diabetes. Due to severe haemoptysis, she reduced the dose of anticoagulant by $50 \%$ without medical consultation. Chest CT performed one month prior to hospitalisation revealed bilateral interstitial opacities with air bronchogram and ground-glass attenuations. The radiological findings suggested interstitial lung disease, and the patient was referred to our Department. On admission the general condition of the patient was severe. She presented dyspnoea in rest and massive haemoptysis. Physical examination showed obesity (BMI 47.5), tachypnoea (30 per minute), tachycardia (105 per minute), and oedema of the ankles. On auscultation, the respiratory sounds over the lower right lobe were diminished, and crackles over the middle right lobe and the whole left lung were detected. The patient had respiratory insufficiency $\left(\mathrm{PaO}_{2}-50 \mathrm{mmHg}, \mathrm{PaCO}_{2}-\right.$ $33 \mathrm{mmHg}, \mathrm{pH}$ 7.48). Laboratory tests revealed an elevated level of C-reactive protein $(26.5 \mathrm{mg} / \mathrm{dl})$, D-dimer $(3991 \mathrm{ng} /$ $\mathrm{ml}$ ) and anaemia (haemoglobin $9 \mathrm{~g} / \mathrm{dl}$, haematocrit 29.7\%). Chest X-ray demonstrated right-sided opacity corresponding to pleural fluid, scattered pulmonary lesions, and moderately enlarged hila (Fig. 1). Computed tomography scans of the chest showed progression of bilateral ground-glass opacities of different shape and size with peripheral predilection, small nodules (including one peripheral left lung nodule with slight cavitation), right-sided pleural effusion, and enlargement of the heart (Fig. 2 and 3). There were no radiological signs of pulmonary embolism in large branches of pulmonary arteries, but a suggestion that small vessels

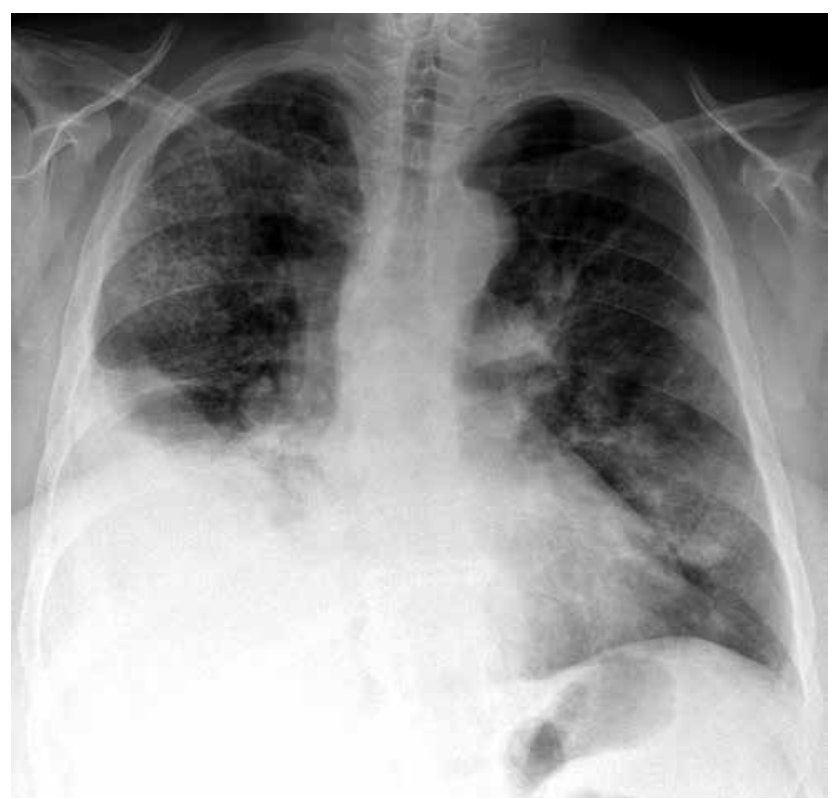

Fig. 1. Chest radiograph shows right-sided opacity corresponding to pleural fluid; diffuse pulmonary lesions focally confluent, forming bigger opacities within left lung; hila moderately enlarged could have been filled with thrombotic material was made. Echocardiography showed enlargement of the right ventricle and both atria, and elevated pulmonary artery pressure at $42 \mathrm{mmHg}$. The values of tumour markers (cancer antigen CA 15-3, CA 19-9, CA 125, carcinoembryonic antigen), antineutrophil cytoplasmic antibody (ANCA), and anti-nuclear antibody (ANA) were in normal range. Ultrasonography of the abdomen did not reveal any pathological masses. Bronchoscopy revealed a bronchi field with a significant amount of fresh blood without any visible point of origin. The bacterial and fungal cultures of bronchial washing were negative. Due to severe dyspnoea, two pleurocenteses were performed. The drainage was close to $1000 \mathrm{ml}$ of bloody fluid. The haematocrit of the effusion was $19.8 \%$ and it was higher than $50 \%$ of the haematocrit of peripheral blood, which met the criteria of true haemothorax. The cytological examination of bronchial washing and pleural fluid was negative for neoplasmatic cells. On suspicion of immunologically-induced intra-alveolar haemorrhage, $80 \mathrm{mg}$ of prednisone was administrated. After a brief stabilisation, videothoracoscopic pleural and lung biopsy was performed. Intra-operative biopsy for frozen section examination did not reveal any neoplasmatic cells. During the next two days after the surgery the condition of the patient was critical and she died a few days after.

Microscopic examination of pleural samples revealed that the areas of slit spaces were filled with erythrocytes and surrounded by epithelioid cells. Immunohistochemical reactions showed diffuse reactivity with anti-CD31 (LC70, Cell Marque) antibody (Fig. 4) and focal anti-CD34 (QBEnd/10, Cell Marque) staining. Reactions with cytokeratins (AE1AE3, Roche) and calretinin (SP65, Roche) were negative. In the lung specimen, cohesive and ill-defined lesions were found. On microscopic examination, the lesions were composed of groups of loosely packed epithelioid cells mixed with fibrin and erythrocytes. Adjacent alveolar spaces were filled with red blood cells and haemosiderin-laden macrophages (Fig. 5). A diagnosis of epithelioid angiosarcoma was established.

\section{Discussion}

Primary epithelioid angiosarcoma of the lung is an extremely rare disease. Typically, angiosarcomas occur as skin and subcutaneous tissue neoplasms of the head, neck, and lower and upper extremities, or involve the heart and extrathoracic organs $[3,4]$. Pulmonary manifestation must be first of all differentiated with metastasis from other organs. There are no typical factors associated with development of these tumours. Some reports suggest a correlation between radiotherapy, chemotherapy, past surgical interventions, environmental carcinogens, or chronic tuberculosis pyothorax $[1,3,6,7]$.

Primary pulmonary angiosarcoma patients complain of haemoptysis, dyspnoea, cough, weight loss, fatigue, pleuritic chest pain, and sometimes fever [3, 8]. Our patient presented most of these symptoms. Nevertheless, due to nonspecific complaints, continuous anticoagulant 


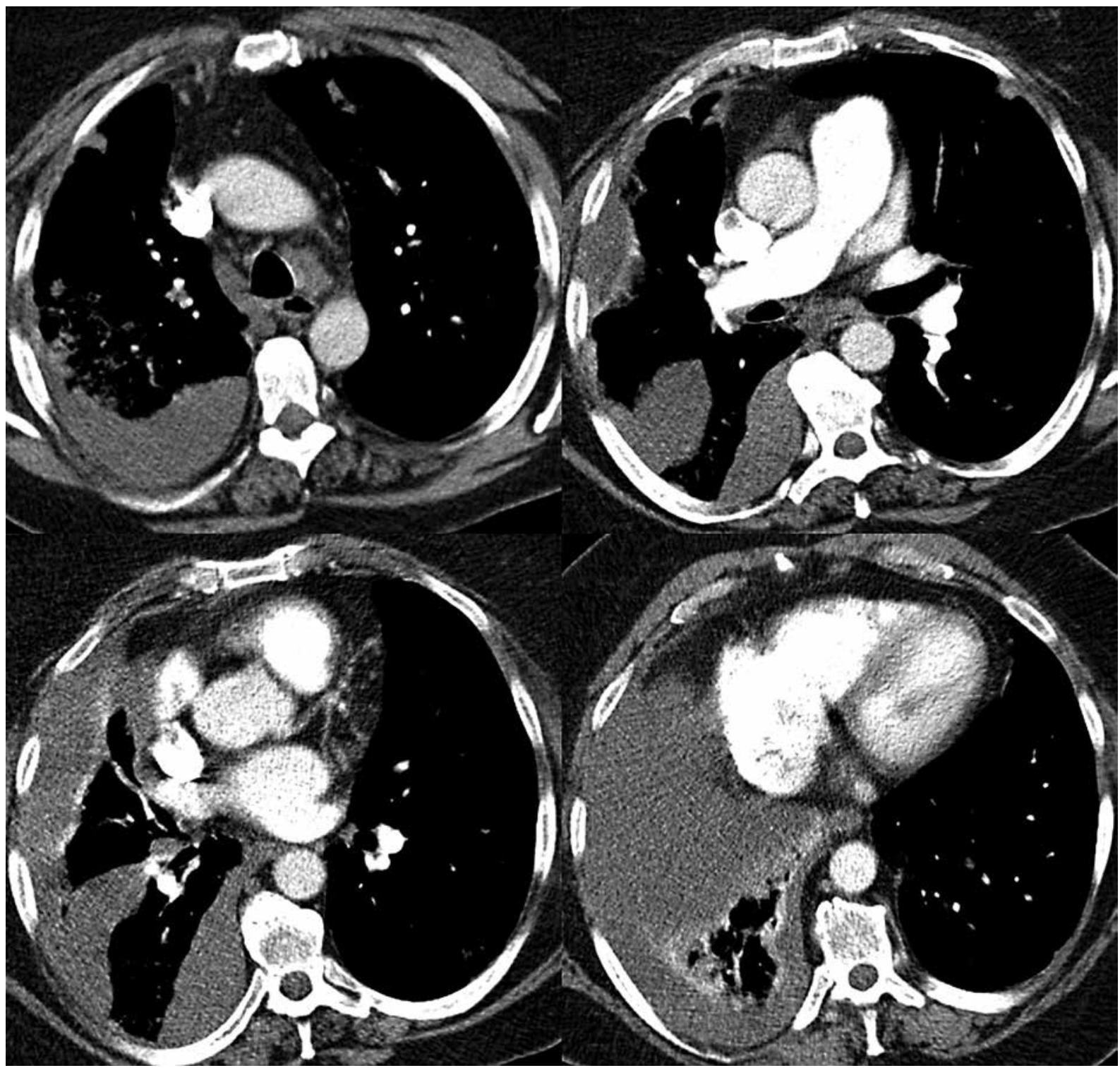

Fig. 2. Computed tomography scan shows a large right pleural effusion

therapy, history of heart disease, misleading radiological features, and rapid progression, the diagnosis was made in a very advanced and metastatic stadium. In the presented case, the clinical condition was also complicated by massive right-sided pleural effusion. The haematocrit of the fluid was higher than $50 \%$ of the haematocrit of peripheral blood, which met the criteria of true haemothorax [9].

There are no differences between PPA and metastatic angiosarcoma of the lung in radiological manifestation. In both cases CT demonstrates solitary or multifocal lesions, sometimes associated with ground-glass opacities or pleural effusion. Usually at the time of diagnosis, the neoplasm presents extensive local and metastatic invasion [1-4]. The first lung CT scan of our patient was confusing. It showed abnormalities suggesting interstitial pneumonia. There were no signs of typical tumour. Radiological changes evolved with the progression of the disease. Images obtained on admission revealed bilateral pulmonary opacities with ground-glass attenuations, a small number of nodules, and pleural effusion. There is only one case reported with this rare presentation of PPA [5].

The histological examination of epithelioid angiosarcomas reveals single or multifocal tumours composed of sheets of atypical epithelioid cells, focal vasoformative areas, and necrosis. Haematoxylin-eosin stained sections show irregularly anastomosing vessels, cells with nuclear atypia, and often a high mitotic count $[4,6]$. The diagnosis needs to be confirmed by immunohistochemical reactions. Factor VIII, CD 31, CD34, Fli-1, Ulex europaeus agglutinin 1, and vimentin are typical endothelial markers $[4,7,8]$. The biopsy specimen of our patient showed positive reaction for $C D 31$ and $C D$ 34. The other stains, including cytokeratin (AE1/AE3) for epithelial and calretinin for mesothelial proliferations, were negative. It is suggested that at least two markers should be present in order to confirm the endothelial origin [8]. 


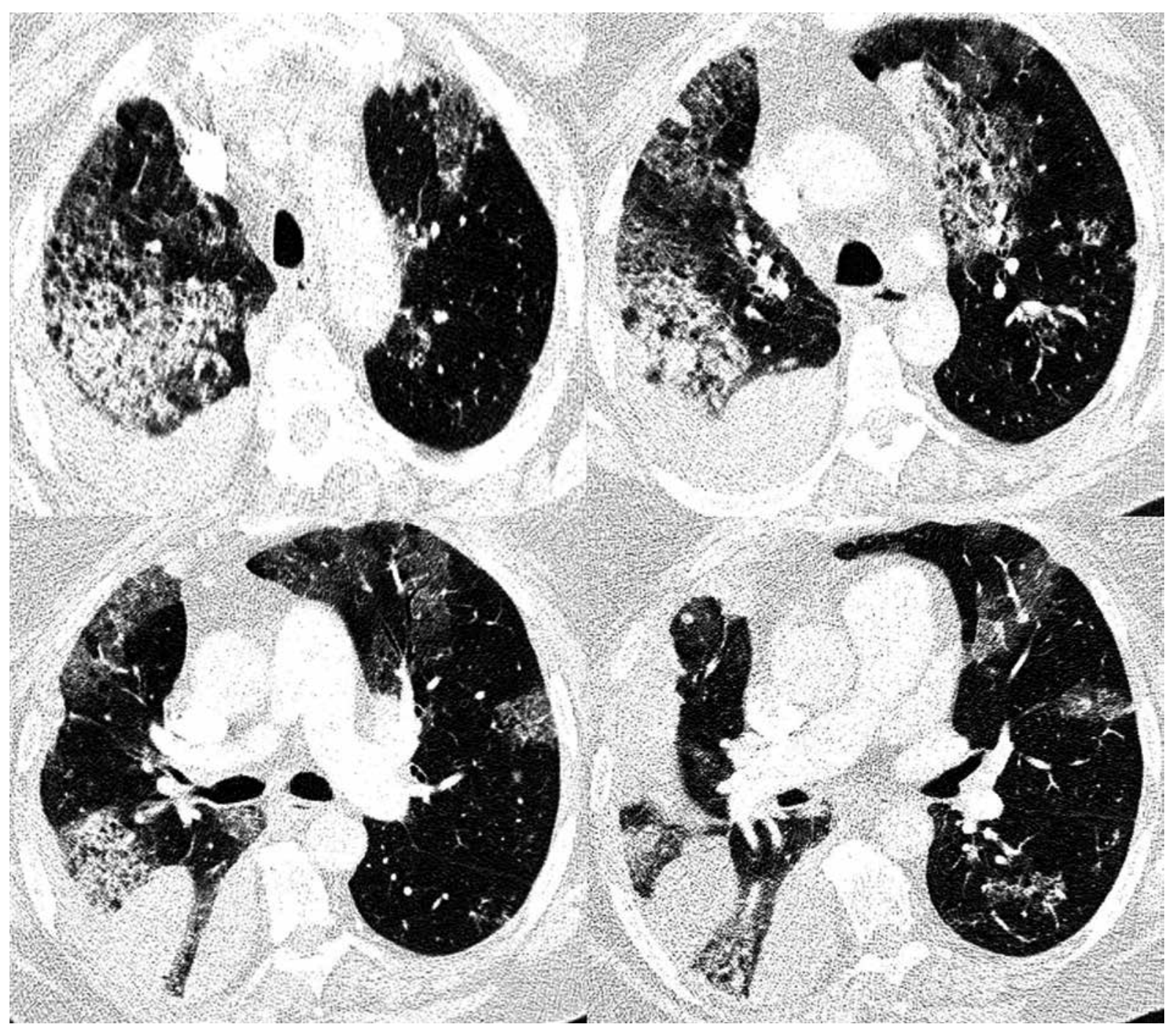

Fig. 3. High-resolution computed tomography (HRCT) scans: multiple ground-glass opacities, predominantly subpleural; some small nodules bilaterally

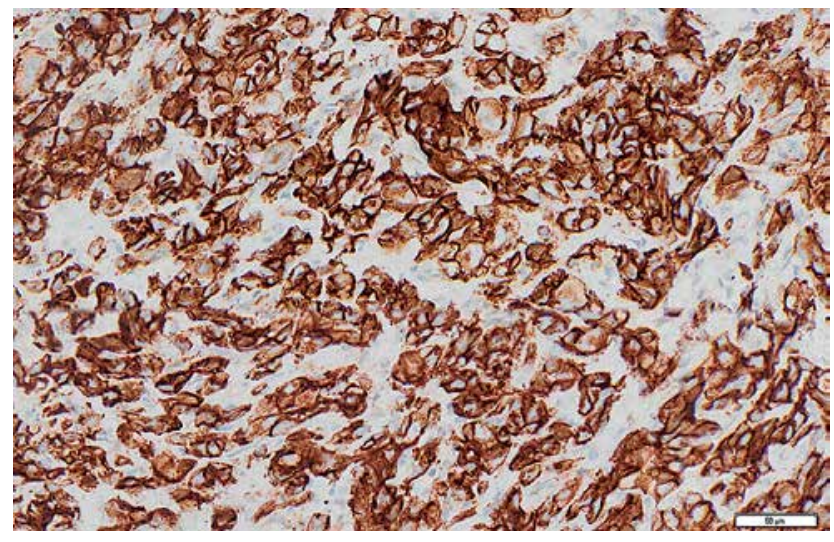

Fig. 4. Epithelioid angiosarcoma, pleural lesion. Epithelioid cells revealed diffuse reactivity with anti-CD31 antibody (CD31, magnification 200x)

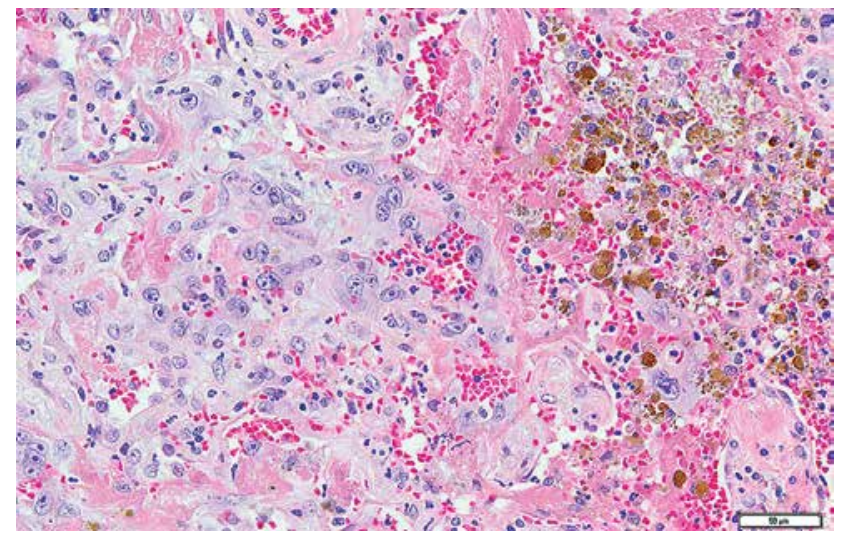

Fig. 5. Epithelioid angiosarcoma. Low- and medium-power magnification of a pulmonary lesion composed of epithelioid cells, haemorrhages, and fibrin deposits surrounded by hyperaemic lung parenchyma with aggregations of haemosiderin-laden macrophages (HE staining, magnification 200x) 
Unfortunately, the survival rate in primary pulmonary manifestation is less than 39 months [8]. There have been reports summarising poor prognostic factors for angiosarcomas, such as age ( $>70$ years), tumour size $(>5 \mathrm{~cm})$, metastases at presentation, grade, and mitotic count, but they are still under debate $[7,10]$.

The presented case is a rare manifestation of primary pulmonary angiosarcoma with diffuse pulmonary haemorrhage and haemothorax. Non-distinctive clinical and radiological symptoms and a rapidly progressive course make this type of neoplasm a considerable challenge for clinicians. Our case is a reminder of the necessity to include PPA in differential diagnosis of diffuse alveolar haemorrhage and haemothorax.

\section{Disclosure}

Authors report no conflict of interest.

\section{References}

1. Patel AM, Ryu JH. Angiosarcoma in the lung. Chest 1993; 103: 1531-1535.

2. Foran P, Colleran G, Madewell J, O'Sullivan PJ. Imaging of thoracic sarcomas of the chest wall, pleura and the lung. Semin Ultrasound CT MR 2011; 32: 365-376.
3. Atasoy C, Fitoz S, Yigit H, Atasoy P, Erden I, Akyar S. Radiographic, CT, and MRI findings in primary pulmonary angiosarcoma. Clin Imaging 2001; 25: 337-340.

4. Obeso Carillo GA, Garcia Fontan EM, Canizares Carretero MA, Perez Pedrosa A. Primary pulmonary angiosarcoma, an exceptional neoplasm with a poor prognosis: reports of two cases and review of the literature. Gen Thorac Cardiovasc Surg 2013; 61: 643-647.

5. Liu SF, Wu CC, Lai YF, Hsieh MJ. Massive hemoptysis and hemothorax caused by pleuropulmonary angiosarcoma. Am J Emerg Med 2002; 20: 374 375.

6. Weissferdt A, Moran CA. Primary vascular tumors of the lungs: a review. Ann Diagn Pathol 2010; 14: 296-308.

7. Young RJ, Brown NJ, Reed MW, Hughes D, Woll PJ. Angiosarcoma. Lancet Oncol 2010; 11: 983-991.

8. Wilson R, Galros R, Brown RK, Michael C, Reisman D. Complete radiographic response of primary pulmonary angiosarcomas following gemcitabine and taxotere. Lung Cancer 2008; 61: 131-136.

9. Moriya Y, Sugawara T, Arai M, Tsuda Y, Uchida K, Noguchi T, Arai T, Takakashi $\mathrm{H}$. Bilateral massive bloody pleurisy complicated by angiosarcoma. Intern Med 2007; 46: 125-128.

10. Lindet C, Neuville A, Penel N, Lae M, Michels JJ, Trassard M, Terrier P, Birtwisle-Peyrottes I, Valo I, Collin F, Chateau MC, Robin YM, Coindre JM. Localised angiosarcomas: the identification of prognostic factors and analysis of treatment impact. A retrospective analysis from the French Sarcoma Group (GSF/GETO). Eur J Cancer 2013; 49: 369-376. 